\title{
PENINGKATAN KEDISIPLINAN GURU MELALUI REWARD AND PUNISHMENT DI SDN KETAWANG KARAY I KECAMATAN GANDING KABUPATEN SUMENEP SEMESTER 1 TAHUN 2017/2018
}

\author{
Ngumpriyatun \\ SDN Ketawang Karay I \\ jengperi7069@gmail.com
}

\begin{abstract}
Abstrak
Suatu pembelajaran dapat terlaksana dengan baik jika guru dapat berperilaku disiplin dalam mengikuti pembelajaran tersebut. Keadaan disiplin merupakan keadaan dimana guru taat terhadap tata tertib atau aturan yang berlaku. Dalam kehadiran, banyak guru di SDN Ketawang Karay I Kecamatan Ganding kabupaten Sumenep yang sering terlambat datang ke sekolah. Hal ini menyebabkan waktu belajar terbuang di pagi hari. Selain itu, dalam pembelajaran masih banyak ditemui guru tidak membuat administrasi kelas dan kelengkapan pembelajaran lainnya. Kepala sekolah mengambil langkah untuk memperbaikai kondisi ini dengan melakukan penelitihan tindakan sekolah untik memperbaiki keadaan. Cara yang dapat digunakan oleh kepala sekolah agar guru dapat berperilaku disiplin adalah dengan pemberian reward (penghargaan) dan punishment (hukuman). Reward And Punishment yang diberikan oleh kepala sekolah akan dapat meningkatkan kedisiplinan guru di SDN Ketawang Karay I Kecamatan Ganding Kabupaten Sumenep.

Penelitian ini menngunakan penelitian tindakan dengan hasil peningkatan kedisiplinan guru melalui Reward And Punishment di SDN Ketawang Karay I Kecamatan Ganding Kabupaten Sumenep Semester 1 Tahun 2017/2018 dapat meningkat. Hal ini terbukti dari hasil kondisi awal, kedisiplinan guru dalam kehadiran (guru hadir tepat waktu) ada 3 guru atau 27,27\%, meningkat lagi pada siklus I guru yang tepat waktut ada 7 atau $63,64 \%$, dan meningkat lagi pada siklus II menjadi 10 atau $90,91 \%$.
\end{abstract}

Kata Kunci: Kedisiplinan Guru, Reward, Punishment

\begin{abstract}
A learning can be done well if the teacher can behave discipline in following the learning. Discipline is a situation where the teacher adheres to the rules or rules that apply. In attendance, many teachers at Ketawang Karay I Elementary School in Ganding Sub-District, Sumenep District, often come late to school. This causes wasted learning time in the morning. In addition, there are still many teachers in learning who do not make classroom administration and complete other learning. The principal takes steps to correct this condition by conducting school actions to improve the situation. Ways that can be used by principals so that teachers can behave in a discipline are by giving rewards and punishment. Reward And Punishment given by the principal will increase the discipline of teachers in Ketawang Karay I Elementary School, Ganding Sub-District, Sumenep Regency.

This research uses action research with the results of increasing teacher discipline through Reward And Punishment in Ketawang Karay I Elementary School, Ganding Sub-District, Sumenep Regency, Semester 1, 2017/2018 can increase. This is evident from the results of the initial conditions, the discipline of the teacher in attendance (the teacher is present on time) there are 3 teachers or $27.27 \%$, increasing again in the first cycle of the teacher's right time there are 7 or $63.64 \%$, and increase again in cycle II to 10 or $90.91 \%$.
\end{abstract}

Keywords: Teacher Discipline, Reward, Punishment 
Ngumpriyatun

\section{Pendahuluan}

Norma dan etika adalah terkait dengan ketentuan waktu dalam melaksanakan tugas dan tanggung jawab profesinya, maka guru harus tepat waktu dalam melaksanakan proses belajar mengajar dan sebagainya. Waktu juga merupakan salah satu "modal" kerja yang sangat terbatas, sehingga harus digunakan secara efisien. Pengalaman selama ini menunjukkan bahwa penggunaan waktu di SDN Ketawang Karay I Kecamatan Ganding Kabupaten Sumenep belum efisien. Masih banyak kebiasaan yang belum memanfaatkan waktus ecara optimal bagi keberhasilan belajar peserta didik. Misalnya, pada jam pertama masuk kegiatan belajar mengajar (KBM) jam 07.00 WIB, akan tetapi guru ataupun peserta didik tidak siap, mereka sepertinya tidak bisa masuk tepat jam 07.00, walaupun ada beberapa guru/peserta didik bisa masuk tepat jam 07.00, namun itupun tidak stabil, sehingga hal ini berdampak pada stabilitas sekolah.

Salah satu factor penyebabnya adalah $70 \%$ jarak tempat tinggal guru dengan sekolah rata-rata di atas $7 \mathrm{~km}$, guru yang tidak memiliki kendaraan pribadi akan merasa kesulitan untuk hadir tepat waktu. Begitu pula dengan jam-jam terakhir, kendaraan umum sudah tidak ada sedangkan mereka juga ingin segera tiba di rumah. Belum lagi kalau cuacanya buruk yang mengakibatkan guru malas untuk kesekolah dengan alas an jarak dan transportasi. Hal ini berdampak pada stabilitas sekolah seperti alokasi waktu guru jadi berkurang, peserta didik berkeliaran di lingkungan sekolah, prestasi belajar peserta didik rendah, dan kepercayaan orang tua terhadap sekolah kurang maksimal.

Kejadian ini terus berulang dan menjadi sisi lemah bagi sekolah dalam meningkatkan mutu pembelajaran maupun dalam meningkatkan kepercayaan serta dukungan orang tua terhadap sekolah. Sebagai pimpinan tertinggi di sekolah, kepala sekolah telah berupaya mengelola waktus ecara efisien, baik untuk tugastugas sendiri maupun untuk sekolah secara keseluruhan. Kebiasaan menggunakan waktu yang produktif oleh kepala sekolah diharapkan dapat menjadi contoh bagi guru, staf administrasi, maupun peserta didik. Disamping itu perlu menyusun rencana penggunaannya serta pemanfaatan waktu kerja hendaknya diprioritaskan pada kegiatan pengajaran, pembinaan kepesertadidikan, dan pengembangan profesionallainnya di bidang kegiatan lain yang bersifat administratif. Fakta dilapangan yang sering kita jumpai disekolah adalah kurangnya disiplin guru, terutama masalah disiplin guru masuk kelas dan tidak membuat administrasi kelas.

Kedisiplinan berasal dari kata dasar disiplin. Riberu (Maria J. Wantah, 2005:139) menjelaskan bahwa istilah disiplin diturunkan dari kata latin diciplina yang berkaitan langsung dengan dua istilah lain, yaitu discere (belajar) dan discipulus (murid). Disiplin diartikan sebagai penataan perilaku, dan peri hidup sesuai dengan ajaran yang dianut. Disiplin merupakan suatu cara untuk membantu anak agar dapat mengembangkan pengendalan diri. Dengan menggunakan disiplin, anak dapat memperoleh suatu batasan untuk memperbaiki tingkah lakunya yang salah. Disiplin juga mendorong, membimbing, dan membantu anak agar memperoleh perasaan puas karena kesetiaan dan kepatuhannya dan mengajarkan kepada anak bagaimana berpikir secara teratur.

Maman Rachman

(1998:168) menyatakan disiplin merupakan sesuatu yang berkenaan dengan pengendalian diri seseorang terhadap bentuk-bentuk aturan. Disiplin pada hakikatnya adalah pernyataan sikap mental dari individu maupun masyarakat yang mencerminkan rasa 
ketaatan, kepatuhan yang didukung oleh kesadaran untuk menunaikan tugas dan kewajiban dalam rangka pencapaian tujuan.

The Liang Gie (Ali Imron, 2012:172) menyatakan disiplin adalah suatu keadaaan tertib dimana orang-orang yang tergabung dalam suatu organisasi tunduk pada peraturan-peraturan yang telah ada dengan rasa senang hati. Good's (Ali Imron, 2012:172) dalam Dictionary of Education mengartikan disiplin sebagai berikut:

a. Proses atau hasil pengarahan atau pengendalian keinginan, dorongan atau kepentingan guna mencapai maksud atau untuk mencapai tindakan yang lebih efektif.

b. Mencari tindakan terpilih dengan ulet, aktif dan diarahkan sendiri meskipun menghadapi rintangan.

c. Pengendalian perilaku secara langsung dan otoriter dengan hukuman atau hadiah.

d. Pengekangan dorongan dengan cara yang tak nyaman dan bahkan menyakitkan.

Berdasarkan uraian di atas, kedisiplinan adalah kepatuhan sesorang terhadap aturan dan tata tertib baik berupa perintah maupun larangan yang berlaku. Disiplin membantu guru untuk mengendalikan perilakunya. Dalam penelitian ini guru diharapkan akan dapat berperilaku disiplin dalam kinerjanya di sekolah.

Kedisiplinan belajar peserta didik di sekolah berkaitan dengan kedisiplinan belajar di dalam kelas. Kedisiplinan belajar di kelas menurut Dirjen PUOD dan Dirjen Dikdasmen (Maman Rachman, 1998: 168) adalah keadaan tertib dalam suatu kelas yang di dalamnya tergabung guru dan guru yang taat kepada tata tertib yang telah ditetapkan. Ketertiban menunjuk pada kepatuhan seseorang dalam mengikuti peraturan atau tata tertib karena didorong atau disebabkan oleh sesuatu yang datang dari luar.
Maman Rachman (1998:170) menyatakan kaitan dengan disiplin di sekolah atau kelas, maka tindak-tanduk yang diharapkan adalah tindak- tanduk yang mencerminkan kepatuhan dari berbagai nilai yang disepakati oleh semua, baik guru, dan karyawannya yang tertuang dalam tata tertib sekolah/kelas.

Dalam upaya penerapan kedisiplinan guru pada kehadiran di kelas dalam kegiatan belajar mengajar, bisa ditempuh dengan beberapa upaya. Adapun upaya dalam meningkatkan disiplin guru adalah sebagai berikut:

a. sekolah memiliki sistem pengendalian ketertiban yang dikelola dengan baik,

b. adanya keteladanan disiplin dalam sikap dan prilaku dimulai dari pimpinan sekolah,

c. mewajibkan guru untuk mengisi agenda kelas dan mengisi buku absen yang diedarkan oleh petugas piket

d. pada awal masuk sekolah kepala sekolah bersama guru membuat kesepakatan tentang aturan kedisiplinan,

e. memperkecil kesempatan guru untuk ijin meninggalkan kelas, dan

f. setiap rapat pembinaan diumumkan frekuensi pelanggaran terendah.

Dengan strategi tersebut diatas kultur disiplin guru dalam kegiatan pembelajaran bisa terpelihara dengan baik, suasana lingkungan belajar aman dan terkendali sehingga guru bisa mencapai prestasi belajar yang optimal.

Banyak sekali dari kita yang mengerti dan paham disiplin tapi ketika ditanya tentang arti disiplin mereka agak kebingungan. Disiplin diri adalah sikap patuh kepada waktu dan peraturan yang ada. Dari pengertian diatas kita dapat menyimpulkan bahwa disiplin itu mengandung dua makna yaitu patuh waktu dan juga peraturan atau tata tertib ataupun norma. 
Ngumpriyatun

Patuh pada waktu, tentunya kita sering mendengar kata disiplin waktu. Disiplin memiliki arti demikian ketika kita dihadapkan pada waktu dalam melakukan sesuatu artinya dalam melakukan sesuatu tersebut kita memiliki sebuah tanggungjawab kepada waktu. Contoh realnya seperti ini, sebagai guru tentu mengetahui jam masuk sekolah kita sehingga kita sebisa mungkin untuk datang ke sekolah lebih awal agar tidak terlambat. Dari contoh tersebut kita dapat mengetahui kalau seorang guru yang disiplin itu memiliki tanggung jawap pada waktu yang berupa jam masuk sekolah.

Patuh pada tata tertib atau peraturan, di sekolah sebagai guru tentunya kita telah mengetahui tata tertib sekolah. Di lingkungan masyarakat kita juga telah mengenal itu norma. Di dalam keluarga juga dapat di temui sebuah aturan meskipun biasa tak tertulis. Disiplin memiliki arti demikian ketika dihadapkan kepada peraturan peraturan atau tata tertib saat ingin melakukan sesuatu. Setiap peraturan itu bersifat mengikat artinya siapapun yang berada pada lingkungan yang memiliki suatu peraturan secara tidak langsung orang tersebut memiliki tanggung jawab pada peraturan tersebut. Ketika orang tersebut mematuhi peraturan tersebut maka ia telah bersikap disiplin dan ketika berbuat sebaliknya dia telah berbuat tidak disiplin dan akan dikenai sanksi sesuai aturan yang berlaku.

Kedua makna ini harus dipenuhi oleh setiap orang jika ingin disebut telah memiliki sikap disiplin diri. Sikap disiplin diri ini merupakan sebuah sikap kebiasaan, artinya sesorang yang telah terbiasa disiplin akan mudah untuk berlaku disiplin di manapun dia berada tetapi ketika seseorang tersebut tidak terbiasa maka dia juga akan sulit untuk berlaku disiplin dimanapun itu.
Salah satu strategi dalam meningkatkan kedisiplinan adalah dengan reward and punishment. Jika guru kinerja dan kedisiplinannya bagus maka layak untuk mendapatkan penghargaan, namun jika sebaliknya guru kinerja dan kedisiplinannya kurang bagus maka layak untuk mendapatkan hukuman. Guru merupakan actor dalam pembelajaran di kelas maka kewajiban seorang actor (guru) harus bisa memberikan contoh yang baik untuk penontonnya (peserta didik).

Maslow (Maria J. Wantah, 2005:164) mengatakan bahwa penghargaan adalah salah satu dari kebutuhan pokok yang mendorong seseorang untuk mengaktualisasikan dirinya. Penghargaan adalah unsur disiplin yang sangat penting dalam pengembangan diri dan tingkah laku anak. Seseorang akan terus berupaya meningkatkan dan mempertahankan disiplin apabila pelaksanaan disiplin itu menghasilkan prestasi dan produktivitas yang kemudian mendapatkan penghargaan.

M. Ngalim Purwanto (2006:182) menjelaskan penghargaan adalah alat untuk mendidik anak -anak supaya anak dapat merasa senang karena perbuatan atau pekerjaannya mendapat penghargaan. Penghargaan harus memiliki nilai mendidik. Mendidik disini tidak hanya dalam bidang akademik tetapi juga mendidik guru dalam bertingkah laku yang baik.

Berdasarkan pendapat diatas dapat disimpulkan bahwa penghargaan adalah suatu hal positif yang diperoleh anak karena anak telah menunjukkan suatu perbuatan yang baik. Pemberian penghargaan kepada anak akan meningkatkan perilaku yang sesuai dengan aturan yang berlaku, serta membuat anak untuk menghindari diri dari perbuatan yang tidak sesuai dengan aturan. Dengan pemberian penghargaan anak akan 
berusaha berperilaku disiplin. Budaya disiplin akan menjadi modal penting dalam pergaulan di masyarakat maupun di dunia kerja.

Sedangkan, Amir Daien Indrakusuma (1993:147) menjelaskan pengertian hukuman sebagai tindakan yang dijatuhkan kepada anak secara sadar dan sengaja sehingga menimbulkan nestapa. Dengan adanya nestapa anak akan menjadi sadar akan perbuatannya dan berjanji di dalam hatinya untuk tidak mengulanginya. Hukuman diberikan apabila teguran dan peringatan belum mampu untuk mencegah anak-anak dalam melakukan pelanggaran.

Ali Imron (2012: 169) berpendapat bahwa hukuman adalah suatu sanksi yang diterima oleh seseorang sebagai akibat dari pelanggaran atau atas aturan-aturan yang telah ditetapkan. Hukuman diberikan sebagai alat pendidikan dimana hukuman yang diberikan harus dapat mendidik dan menyadarkan peserta didik.

M. Ngalim Purwanto (2006:186) memberikan pendapat bahwa hukuman adalah penderitaan yang diberikan atau ditimbulkan dengan sengaja oleh seseorang (orang tua, guru, dan sebagainya) sesudah terjadi suatu pelanggaran, kejahatan atau kesalahan. Pelanggaran bisa berupa pelanggaran terhadap aturan yang berlaku. Masalah hukuman merupakan masalah yang etis, yang menyangkut soal buruk dan baik serta norma-norma.

Dari beberapa pendapat di atas, dapat ditarik kesimpulan bahwa hukuman adalah suatu perbuatan yang kurang menyenangkan yang dilakukan secara sadar dan sengaja karena terjadinya suatu pelanggaran terhadap aturan. Dengan pemberian hukuman seseorang yang melanggar akan sadar akan pelanggarannya dan tidak mengulanginya lagi. Kesadaran harus menjadi faktor penting sehingga dapat menjadi bagian dari budaya hidup, bukan karena keterpaksaan atau tekanan.

\section{Metode Penelitian}

Jenis penelitian yang digunakan yaitu penelitian tindakan sekolah dengan pendekatan kuantitatif. Penelitian tindakan sekolah dapat diartikan sebagai penelitian tidakan dalam bidang pendidikan yang dilaksanakan dalam kawasan sekolah, tujuannya untuk memperbaiki dan meningkatkan kualitas pembelajaran dan kedisiplinan guru.

Penelitian tindakan sekolah yang dilakukan untuk meningkatkan kedisiplinan guru SDN Ketawang Karay I Kecamatan Ganding Kabupaten Sumenep dengan menggunakan Reward And Punishment sebagai tindakannya. Tujuannya untuk meningkatkan kedisiplinan guru dengan memperbaiki disiplin waktu, disiplin administrasi dan disiplin dalam proses pembelajaran.

Tempat penelitian adalah tempat yang digunakan dalam melakukan penelitian untuk memperoleh data yang diinginkan. Penelitian ini bertempat di SDN Ketawang Karay I Kecamatan Ganding Kabupaten Sumenep. Untuk sasaran penelitian adalah guru-guru di SDN Ketawang Karay I Kecamatan Ganding Kabupaten Sumenep Tahun pelajaran 2017/2018 yang berjumlah 11 guru, 8 guru laki-laki dan 3 guru perempuan. Adapun variabel penelitian ini ada 2, yaitu:

1. Variabel Bebas

Dalam penelitian ini yang menjadi variabel bebasnya adalah Peningkatan kedisiplinan guru melalui Reward And Punishment di SDN Ketawang Karay I Kecamatan Ganding Kabupaten Sumenep. Adapun penelitian dari variabel tersebut adalah :

a. Kepala sekolah memberikan reward kepada guru yang disiplin 
Ngumpriyatun

b. Kepala sekolah memberikan punishment kepada guru yang tidak disiplin

c. Guru meningkatkan kedisiplinannya karena adanya Reward And Punishment.

2. Variabel Terikat

Dalam penelitian ini, variabel terikatnya adalah Kedisiplinan guru di SDN Ketawang Karay I Kecamatan Ganding Kabupaten Sumenep. Adapun indikator dari variabel tersebut adalah :

a. Displin waktu

b. Disiplin administrasi kelas

c. Disiplin dalam proses pembelajaran Teknik pengumpulan data yang digunakan dalam penelitian ini adalah: dokumentasi, observasi atau pengamatan. Dokumentasi dimaksudkan untuk mendapatkan gambaran hasil belajar peserta didik sebagai indikator efektifitas proses belajar mengajar guru yang tercermin dalam nilai rata-rata yang diperoleh peserta didik pada setiap kali pertemuan. Sedangkan observasi dan pengamatan dilakukan untuk memperoleh gambaran tentang keadaan disiplin guru baik disiplin waktu maupun dalam pengadaan administrasi perangkat pembelajaran. Teknik pengumpulan data tersebut dapat dijelaskan sebagai berikut:

1. Dokumentasi

Dokumentasi merupakan metode pengumpulan data yang bertujuan untuk memperoleh informasi terkait indentitas, catatan peserta didik, hasil tes (pretest dan postest), dokumen pelaksanaan kegiatan tindakan, foto-foto pelaksanaan pembelajaran, dan catatan kegiatan tindakan.

2. Observasi atau Pengamatan

Observasi merupakan teknik pengumpulan data dengan cara mengamati setiap kejadian yang sedang berlangsung, lalu mencatat setiap hal-hal atau kejadian yang dianggap penting pada saat penelitian. Dalam penelitian ini jenis observasi yang digunakan yaitu observasi partisipatif. Observasi partisipatif merupakan observasi yang dikakukan ketika observer ikut dalam kegiatan yang dilakukan observan. Pada penelitian ini peneliti melibatkan diri selama pembelajaran untuk mendapat data. Observasi ini dilakukan dengan menggunakan chek list yang telah dibuat oleh peneliti pada lembar observasi. Kemudian memberikan tanda centang (") pada rentang skor yang telah ditentukan untuk lembar observasi guru dalam hal kedisiplinan waktu, kedisiplinan administrasi dan kedisiplinan dalam proses pembelajran. Selain itu peneliti membuat catatan harian untuk pendukung kelengkapan data.

\section{Hasil dan Pembahasan Kondisi Awal}

Berikut adalah daftar kedisipliunan guru dalam hal tertib waktu atau tidak terlambat berangkat sekolah, yaitu: 
Tabel 4.1

Daftar Disiplin Waktu Guru Pada Kondisi awal

\begin{tabular}{|c|l|c|c|c|}
\hline \multirow{2}{*}{ NO } & \multirow{2}{*}{ NAMA GURU } & \multicolumn{2}{|c|}{ Kondisi Awal } & \multirow{2}{*}{ Ket. } \\
\cline { 3 - 4 } & & $\begin{array}{c}\text { Tidak } \\
\text { Terlambat }\end{array}$ & Terlambat & \\
\hline 1 & GURU A & Tidak Terlambat & & \\
\hline 2 & GURU B & Tidak Terlambat & & \\
\hline 3 & GURU C & & Terlambat & \\
\hline 4 & GURU D & & Terlambat & \\
\hline 5 & GURU E & Tidak Terlambat & & \\
\hline 6 & GURU F & & Terlambat & \\
\hline 7 & GURU G & & Terlambat & \\
\hline 8 & GURU H & & Terlambat & \\
\hline 9 & GURU I & & Terlambat & \\
\hline 10 & GURU J & & Terlambat & \\
\hline 11 & GURU K & & Terlambat & \\
\hline \multicolumn{2}{|c|}{ Jumlah } & 3 & 8 & \\
\hline \multicolumn{2}{|c|}{ Persentase } & $27,27 \%$ & $72,73 \%$ & \\
\hline
\end{tabular}

Berdasarkan data di atas dapat dilihat bahwa guru yang terlambat ada 8 orang guru atau $72,73 \%$, sedangkan guru yang datang tepat waktu hanya ada 3 orang guru atau $27,27 \%$. Hal ini menyebabkan beberapa kelas tidak terkontrol dan banyak waktu belajar yang terbuang. Saat datang guru juga dalam keadaan lelah sehingga tidak bisa langsung mengajar karena harus melalui proses penyesuaian yang cukup lama dan menyita waktu belajar. Data tersebut disajikan dalam diagram batang seperti di bawah ini.

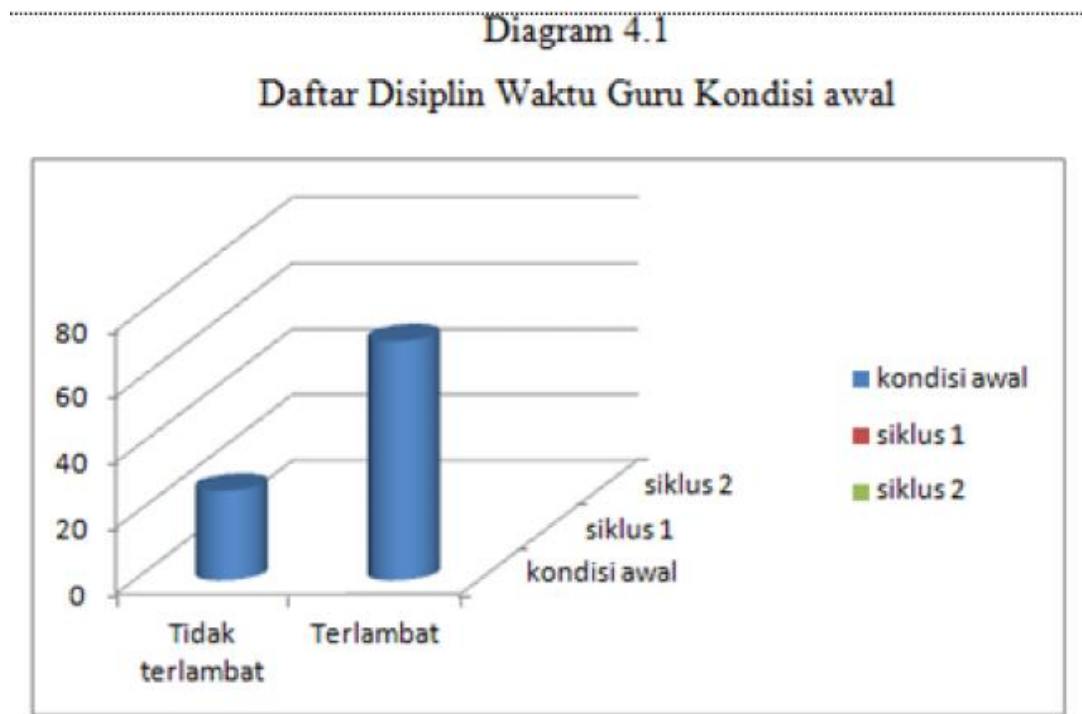


Ngumpriyatun

Hasil pemeriksaan administrasi guru

memmuaskan, secara lengkap dijelaskan pada kondisi awal juga kurang pada tabel di bawah ini.

Tabel 4.2

Rekap Nilai Disiplin Administrasi Guru Pada Kondisi awal

\begin{tabular}{|c|l|l|c|c|}
\hline NO & NAMA GURU & KELENGKAPAN & NILAI & KET \\
\hline 1 & GURU A & Lengkap & 70 & B \\
\hline 2 & GURU B & Cukup Lengkap & 66 & C \\
\hline 3 & GURU C & Lengkap & 75 & B \\
\hline 4 & GURU D & Kurang Lengkap & 55 & K \\
\hline 5 & GURU E & CukupLengkap & 56 & C \\
\hline 6 & GURU F & CukupLengkap & 58 & C \\
\hline 7 & GURU G & CukupLengkap & 75 & B \\
\hline 8 & GURU H & CukupLengkap & 59 & C \\
\hline 9 & GURU I & CukupLengkap & 60 & C \\
\hline 10 & GURU J & Lengkap & 73 & B \\
\hline 11 & GURU K & Kurang Lengkap & 50 & K \\
\hline & Jumlah & & 697 & \\
\hline \multicolumn{2}{|c|}{ Rata-rata } & & 63,36 & \\
\hline \multicolumn{2}{|c|}{ Lengkap } & & $36,36 \%$ & \\
\hline \multicolumn{2}{|c|}{ Kurang lengkap } & & $63,64 \%$ & \\
\hline
\end{tabular}

Berdasarkan data di atas dapat dilihat bahwa guru yang administrasinya lengkap hanya 4 orang guru atau $36,36 \%$, sedangkan guru yang administrasinya kurang lengkap ada 7 orang guru atau $63,74 \%$. Data tersebut disajikan dalam diagram batang seperti di bawah ini.

Diagram 4.2

Disiplin Administrasi Guru Kondisi awal

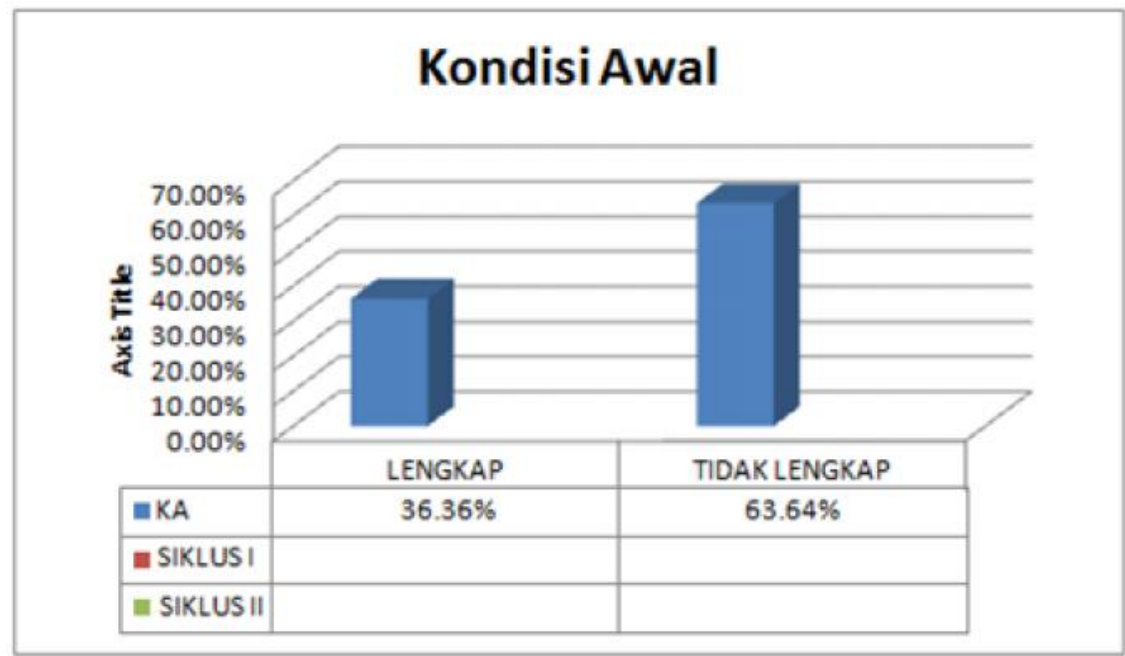


Kehadiran guru dan kelengkapan administrasi kelas diharapkan dapat mendukung pembelajaran yang efektif dan bermakna. Pembelajaran bermakna dimaksud adalah suatu proses yang melibatkan peserta didik secara aktif dalam proses pemerolehan informasi atau pengetahuan yang bermakna bagi pengembangan potensi diri dan prestasinya. Hasil pengamatan pembelajaran guru pada kondisi awal juga kurang memuaskan, secara lengkap dijelaskan pada tabel di bawah ini.

Tabel 4.3

Disiplin dalam Proses Pembelajaran Guru Pada Kondisi awal

\begin{tabular}{|c|c|c|c|c|}
\hline \multirow[b]{2}{*}{ No } & \multirow[b]{2}{*}{ Nama Guru } & \multicolumn{2}{|c|}{ Kondisi Awal } & \multirow[b]{2}{*}{ Ket } \\
\hline & & $\begin{array}{c}\text { Tercapai } \\
\text { Proses } \\
\text { pembelajaran }\end{array}$ & $\begin{array}{c}\text { Tidak Tercapai } \\
\text { Proses } \\
\text { pembelajaran }\end{array}$ & \\
\hline 1 & GURU A & $\sqrt{ }$ & & \\
\hline 2 & GURU B & & $\sqrt{ }$ & \\
\hline 3 & GURU C & $\sqrt{ }$ & & \\
\hline 4 & GURU D & & $\sqrt{ }$ & \\
\hline 5 & GURUE & & $\sqrt{ }$ & \\
\hline 6 & GURU F & & $\sqrt{ }$ & \\
\hline 7 & GURU G & $\sqrt{ }$ & & \\
\hline 8 & GURU H & & $\sqrt{1}$ & \\
\hline 9 & GURU I & $\sqrt{ }$ & & \\
\hline 10 & GURU J & & $\sqrt{ }$ & \\
\hline 11 & GURU K & & $\sqrt{ }$ & \\
\hline \multicolumn{2}{|r|}{ JUMLAH } & 4 & 7 & \\
\hline \multicolumn{2}{|c|}{ PERSENTASE } & $36,36 \%$ & $63,64 \%$ & \\
\hline
\end{tabular}

Berdasarkan data di atas dapat dilihat bahwa guru yang tercapai proses pembelajaran hanya 4 orang guru atau $36,36 \%$, sedangkan guru yang tidak tercapai proses pembelajaran ada 7 orang guru atau 63,74\%. Jika dibuat dalam bentuk diagram yaitu:

Diagram 4.3

Disiplin dalam Proses Pembelajaran Guru Kondisi awal

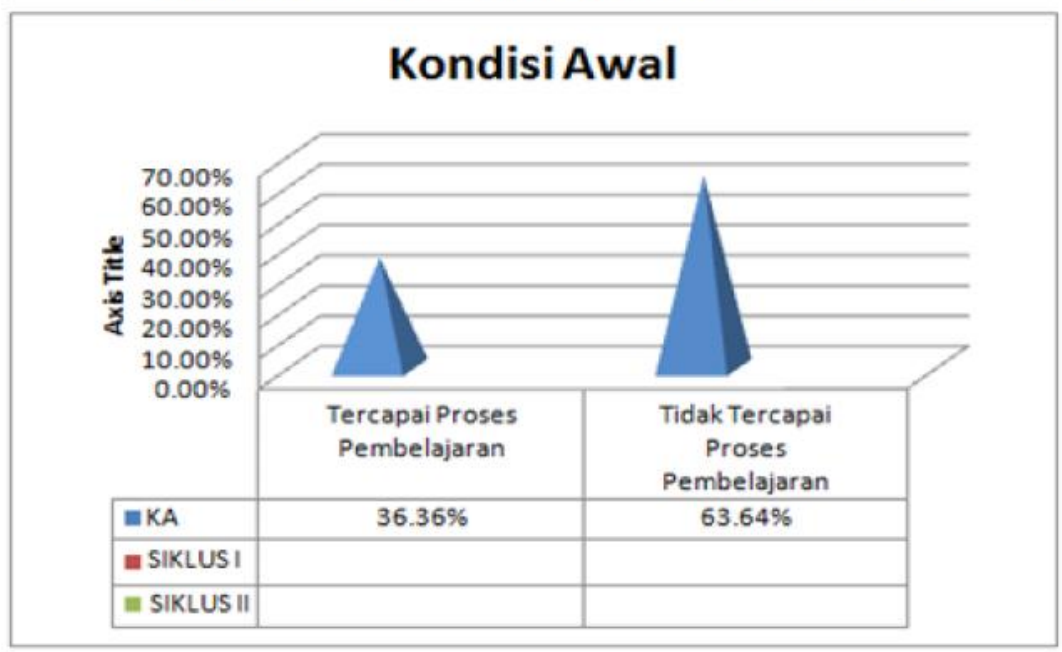

Peningkatan Kedisiplinan Guru Melalui Reward dan Punishment....... 


\section{Siklus I}

Dari hasil pengamatan serta rekap dari tingkat kehadiran guru di kelas pada proses belajar mengajar dapat dilihat pada tabel berikut:

Tabel 4.4

Daftar Disiplin Waktu Guru Pada Siklus 1

\begin{tabular}{|c|c|c|c|c|}
\hline \multirow{2}{*}{ No } & \multirow{2}{*}{ NAMA GURU } & \multicolumn{2}{|c|}{ Kondisi awal } & \multirow[b]{2}{*}{ KEI } \\
\hline & & $\begin{array}{l}\text { Tidak } \\
\text { Terlambat }\end{array}$ & Terlambat & \\
\hline 1 & GURU A & $\begin{array}{l}\text { Tidak } \\
\text { Terlambat }\end{array}$ & & \\
\hline 2 & GURU B & $\begin{array}{l}\text { Tidak } \\
\text { Terlambat }\end{array}$ & & \\
\hline 3 & GURU C & $\begin{array}{l}\text { Tidak } \\
\text { Terlambat }\end{array}$ & & \\
\hline 4 & GURU D & $\begin{array}{l}\text { Tidak } \\
\text { Terlambat }\end{array}$ & & \\
\hline 5 & GURU E & $\begin{array}{l}\text { Tidak } \\
\text { Terlambat }\end{array}$ & & \\
\hline 6 & GURU F & & Terlambat & \\
\hline 7 & GURU G & $\begin{array}{l}\text { Tidak } \\
\text { Terlambat }\end{array}$ & & \\
\hline 8 & GURU H & & Terlambat & \\
\hline 9 & GURU I & $\begin{array}{l}\text { Tidak } \\
\text { Terlambat }\end{array}$ & & \\
\hline 10 & GURU J & & Terlambat & \\
\hline 11 & GURU K & & Terlambat & \\
\hline & Jumlah & 7 & 4 & \\
\hline & Persentase & $63,64 \%$ & $36,36 \%$ & \\
\hline
\end{tabular}

Berdasarkan data di atas dapat dilihat yang terlambat ada 4 orang guru atau bahwa guru yang tidak terlambat hanya $7 \quad 36,36 \%$. Jika dibuat dalam bentuk diagram orang guru atau $63,64 \%$, sedangkan guru yaitu:

Diagram 4.4

Daftar Disiplin Waktu Guru Siklus 1

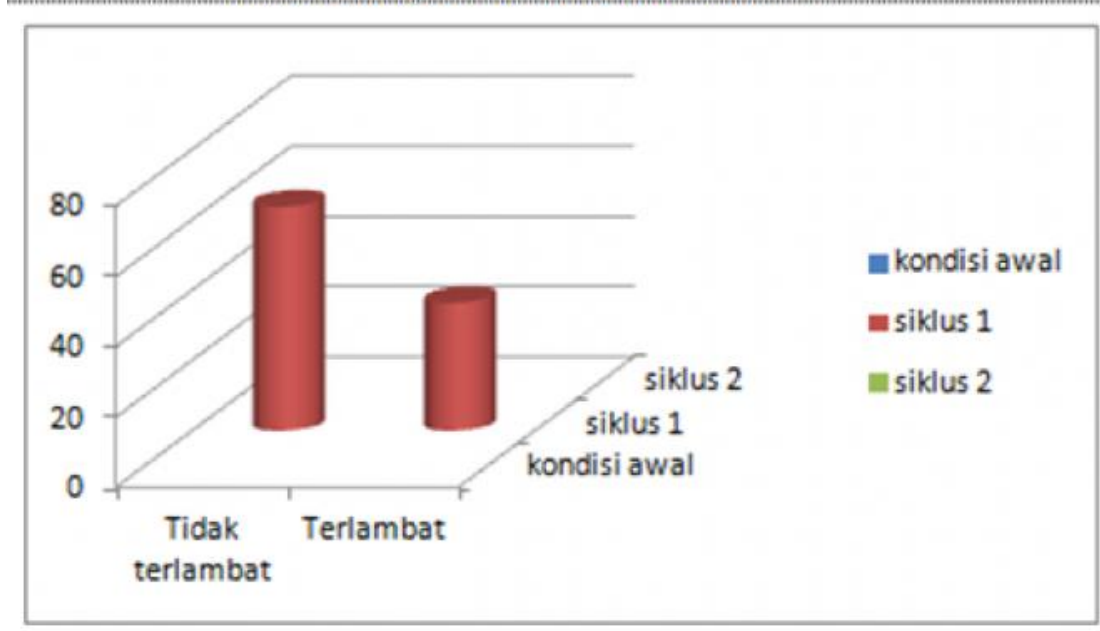


Dari hasil pengamatan terhadap pembelajaran di kelas dapat dilihat pada kedisiplinan guru menyusun administrasi tabel berikut:

\begin{tabular}{|c|c|c|c|c|}
\hline No & NAMA GURU & KELENGKAPAN & NILAI & KET \\
\hline 1 & GURU A & Lengkap & 80 & B \\
\hline 2 & GURU B & Lengkap & 76 & B \\
\hline 3 & GURU C & Lengkap & 86 & B \\
\hline 4 & GURU D & CukupLengkap & 60 & $\mathrm{C}$ \\
\hline 5 & GURU E & Lengkap & 78 & B \\
\hline 6 & GURU F & Lengkap & 75 & B \\
\hline 7 & GURU G & Lengkap & 85 & B \\
\hline 8 & GURU H & Lengkap & 84 & B \\
\hline 9 & GURU I & CukupLengkap & 69 & $\mathrm{C}$ \\
\hline 10 & GURU J & CukupLengkap & 68 & $\mathrm{C}$ \\
\hline 11 & GURU K & CukupLengkap & 59 & $\mathrm{C}$ \\
\hline & Jumlah & & 820 & \\
\hline & Rata-rata & & 74,55 & \\
\hline & Lengkap & 7 & $63,64 \%$ & \\
\hline & Kurang lengkap & 4 & $36,36 \%$ & \\
\hline
\end{tabular}

Berdasarkan data di atas dapat dilihat guru yang administrasinya kurang lengkap bahwa guru yang administrasinya lengkap ada 4 orang guru atau $36,36 \%$. Jika dibuat ada 7 orang guru atau $63,64 \%$, sedangkan dalam bentuk diagram yaitu:

Diagram 4.5

Disiplin Administrasi Guru Siklus I

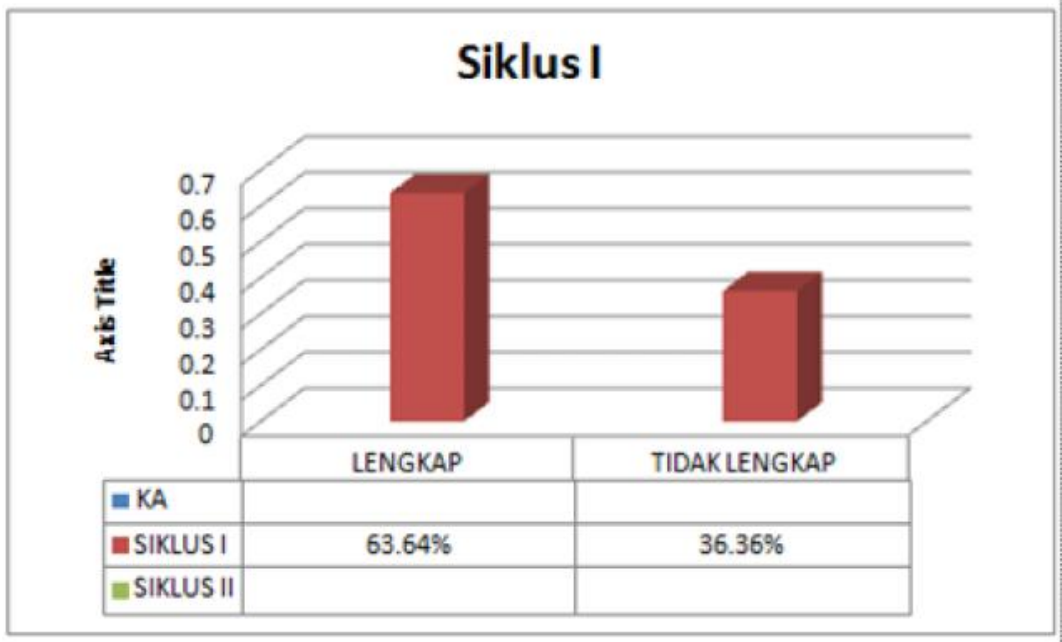


Ngumpriyatun

Dari hasil pengamatan terhadap embelajaran di kelas dapat dilihat pada kedisiplinan guru melaksanakan tabelberikut:

Tabel 4.6

Disiplin dalam Proses Pembelajaran Guru Pada Siklus I

\begin{tabular}{|c|l|c|c|c|}
\hline \multirow{2}{*}{ No } & \multirow{2}{*}{ Nama Guru } & $\begin{array}{c}\text { Tercapai } \\
\text { Proses } \\
\text { pembelajaran }\end{array}$ & $\begin{array}{c}\text { Tidak Tercapai } \\
\text { Proses pembelajaran }\end{array}$ & \\
\hline 1 & GURU A & $\sqrt{ }$ & & Ket \\
\hline 2 & GURU B & $\sqrt{ }$ & & \\
\hline 3 & GURU C & $\sqrt{ }$ & & \\
\hline 4 & GURU D & $\sqrt{ }$ & & \\
\hline 5 & GURU E & $\sqrt{ }$ & & \\
\hline 6 & GURU F & & & \\
\hline 7 & GURU G & $\sqrt{ }$ & \\
\hline 8 & GURU H & & & \\
\hline 9 & GURU I & $\sqrt{ }$ & & \\
\hline 10 & GURU J & $\sqrt{ }$ & & \\
\hline 11 & GURU K & & & \\
\hline \multicolumn{2}{|c|}{ JUMLAH } & 8 & & \\
\hline \multicolumn{2}{|c|}{ PERSENTASE } & $72,73 \%$ & $27,27 \%$ & \\
\hline
\end{tabular}

Data di atas dapat dilihat bahwa guru yang tidak tercapai proses pembelajaran yang tercapai proses pembelajaran ada 8 ada 3 orang guru atau $27,27 \%$. Jika dibuat orang guru atau $72,73 \%$, sedangkan guru dalam bentuk diagram yaitu:

Diagram 4.6

Disiplin dalam Proses Pembelajaran Guru Siklus I

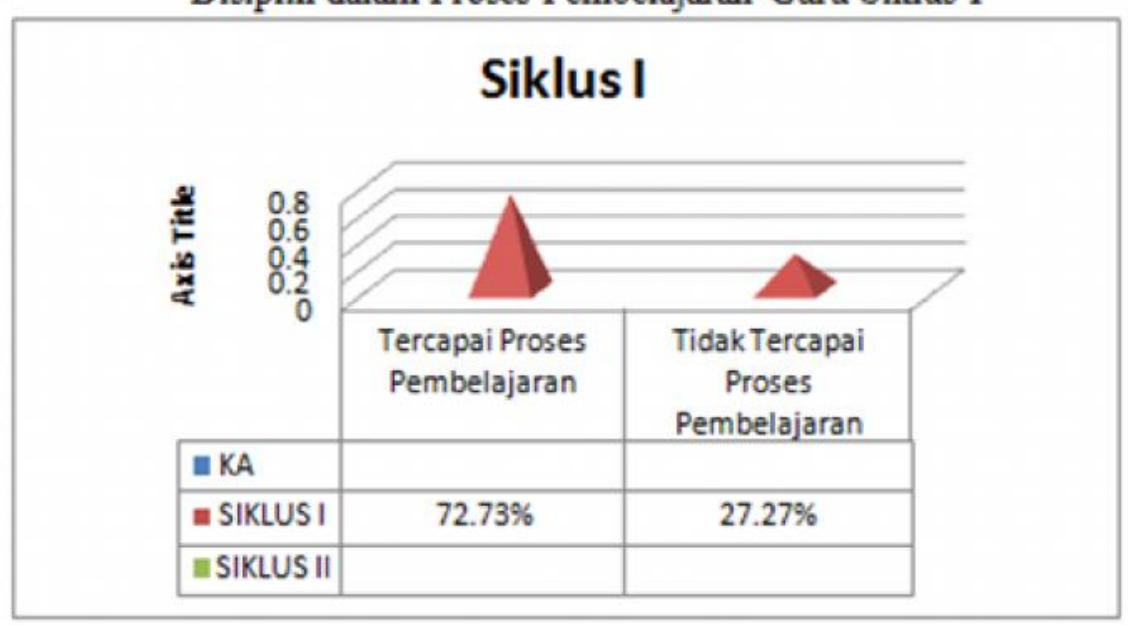

Berdasarkan dokumen evalusi berupa pembelajaran yang didapat dari setiap guru ketercapaian kegiatan proses diperoleh data sebagai berikut: 8 orang 
atau sekitar $72,73 \%$ mencapai target kegiatan pembelajaran, dan 3 orang atau $27,27 \%$ tidak mencapai target kegiatan pembelajaran.

Berdasarkan pelaksanaan tindakan pada siklus I menunjukan bahwa disiplin waktu guru sudah mengalami peningkatan yang pada awalnya hanya sekitar $27,27 \%$ saja pada siklus I ini sudah mencapai $63,64 \%$, demikian halnya dalam disiplin dalam mengadakan persiapan perangkat pembelajaran yang tadinya hanya $36,36 \%$ atau 4 guru dari jumlah guru pada siklus I sudah meningkat mencapai $63,64 \%$ atau 7 guru.

Hal ini ternyata memiliki dampak terhadap kegiatan proses pembelajaran di kelas, hal ini tercermin dari ketercapaian target proses pembelajaran yang menstandarkan pada KKM tiap mata pelajaran masing-masing. Pada kondisi awal ketercapaian target kurikulum hanya berkisar pada $36,36 \%$ saja, sedangkan pada siklus I mencapai peningkatan $72,73 \%$. Ini menunjukkan kenaikan yang cukup memuaskan walaupun belum mencapai target yang diinginkan yakni sekurang-kurangnya mencapai $75 \%$.

\section{Siklus II}

Dari hasil pengamatan serta rekap dari tingkat kehadiran guru dikelas pada proses belajar mengajar pada siklus kedua dapat dilihat pada tabel berikut:

Tabel 4.7

Daftar Disiplin Waktu Guru Pada Siklus II

\begin{tabular}{|c|c|c|c|c|}
\hline \multirow{2}{*}{ No } & \multirow{2}{*}{ NAMA GURU } & \multicolumn{2}{|c|}{ Kondisi awal } & \multirow[b]{2}{*}{ KET } \\
\hline & & Tidak Terlambat & Terlambat & \\
\hline 1 & GURU A & Tidak Terlambat & & \\
\hline 2 & GURU B & Tidak Terlambat & & \\
\hline 3 & GURU C & Tidak Terlambat & & \\
\hline 4 & GURU D & Tidak Terlambat & & \\
\hline 5 & GURU E & Tidak Terlambat & & \\
\hline 6 & GURU F & Tidak Terlambat & & \\
\hline 7 & GURU G & Tidak Terlambat & & \\
\hline 8 & GURU H & Tidak Terlambat & & \\
\hline 9 & GURU I & Tidak Terlambat & & \\
\hline 10 & GURU J & Tidak Terlambat & & \\
\hline 11 & GURU K & & terlambat & \\
\hline & Jumlah & 10 & 1 & \\
\hline & Persentase & $90,91 \%$ & $9,09 \%$ & \\
\hline
\end{tabular}

Berdasarkan data di atas dapat dilihat ada peningkatan dari siklus sebelumnya bahwa guru yang tidak terlambat hanya 10 orang guru atau $90,91 \%$, sedangkan guru yang terlambat ada 1 orang guru atau $9,09 \%$. Jika dibuat dalam bentuk diagram yaitu: 
Ngumpriyatun

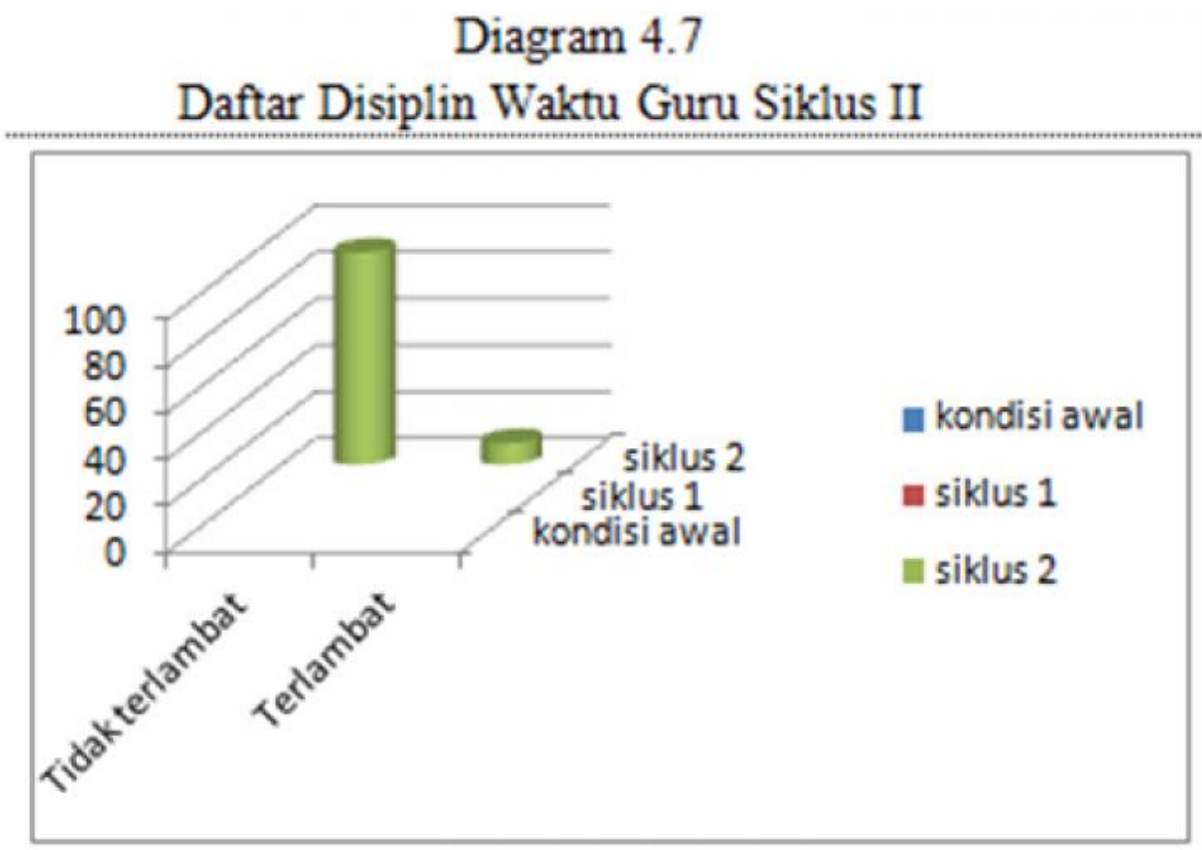

Dari hasil pengamatan terhadap tingkat administrasi kelas pada siklus kedua dapat kedisiplinan guru dalam menyusun dilihat pada tabel berikut:

Tabel 4.8

Rekap Nilai Disiplin Administrasi Guru Pada Siklus II

\begin{tabular}{|c|l|l|c|l|}
\hline NO & NAMA GURU & KELENGKAPAN & NILAI & KET \\
\hline 1 & GURU A & Sangat Lengkap & 100 & SB \\
\hline 2 & GURU B & Sangat Lengkap & 95 & SB \\
\hline 3 & GURU C & Sangat Lengkap & 100 & SB \\
\hline 4 & GURU D & Sangat Lengkap & 87 & SB \\
\hline 5 & GURU E & Sangat Lengkap & 86 & SB \\
\hline 6 & GURU F & Sangat Lengkap & 85 & SB \\
\hline 7 & GURU G & Sangat Lengkap & 88 & SB \\
\hline 8 & GURU H & Sangat Lengkap & 87 & SB \\
\hline 9 & GURU I & Sangat Lengkap & 89 & SB \\
\hline 10 & GURU J & Sangat Lengkap & 90 & SB \\
\hline 11 & GURU K & Lengkap & 85 & B \\
\hline \multicolumn{2}{|l|}{ Jumlah } & & 992 & \\
\hline & Rata-rata & & 90,18 & \\
\hline & Lengkap & & $100 \%$ & \\
\hline \multicolumn{2}{|r|}{ Kurang lengkap } & & $0, \%$ & \\
\hline
\end{tabular}


Berdasarkan data di atas dapat dilihat guru yang administrasinya kurang lengkap bahwa guru yang administrasinya lengkap tidak ada. Jika dibuat dalam bentuk diaada 11 orang guru atau $100 \%$, sedangkan gram yaitu:

Diagram 4.8

Disiplin Guru Menyusun Administrasi Kelas Siklus II

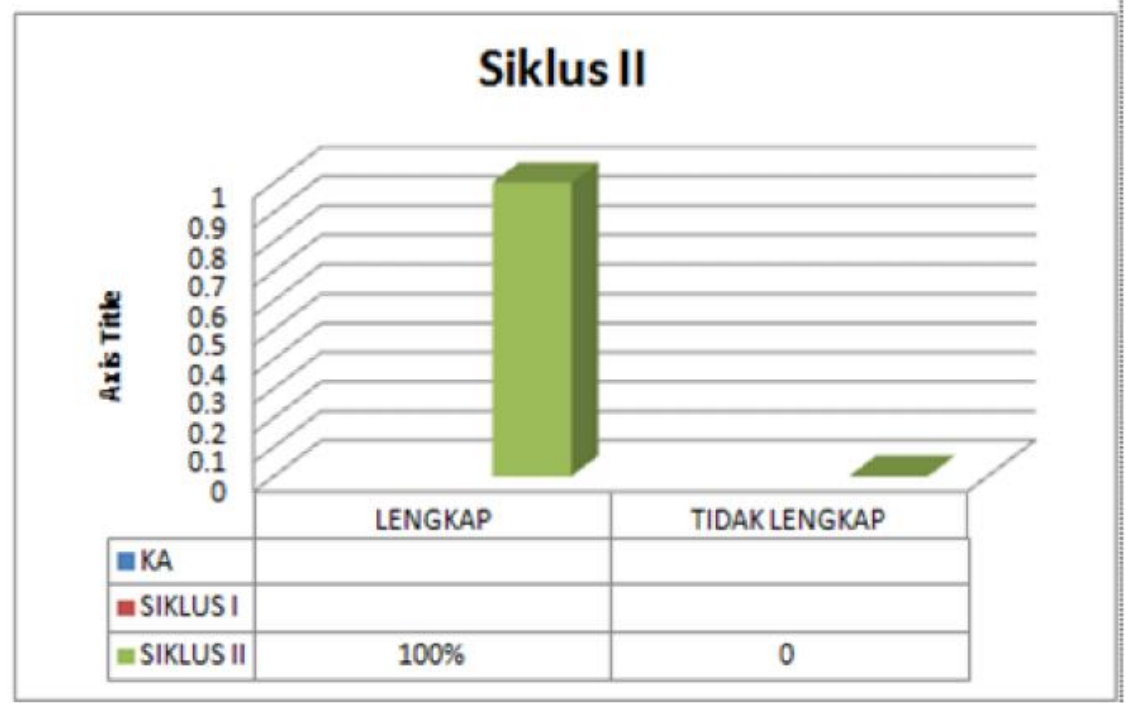

Dari hasil pengamatan terhadap tingkat pembelajaran pada siklus kedua dapat kedisiplinan guru dalam melaksanakan dilihat pada tabel berikut:

Tabel 4.9

Disiplin dalam Proses Pembelajaran Guru Pada Siklus II

\begin{tabular}{|c|c|c|c|c|}
\hline \multirow[b]{2}{*}{ No } & \multirow[b]{2}{*}{ Nama Guru } & \multicolumn{2}{|c|}{ Kondisi Awal } & \multirow[t]{2}{*}{ Ket } \\
\hline & & $\begin{array}{c}\text { Tercapai } \\
\text { Proses } \\
\text { pembelajaran }\end{array}$ & $\begin{array}{c}\text { Tidak Tercapai } \\
\text { Proses pembelajaran }\end{array}$ & \\
\hline 1 & GURU A & $\sqrt{ }$ & & \\
\hline 2 & GURU B & $\sqrt{ }$ & & \\
\hline 3 & GURU C & $\sqrt{ }$ & & \\
\hline 4 & GURU D & $\sqrt{ }$ & & \\
\hline 5 & GURU E & $\sqrt{ }$ & & \\
\hline 6 & GURU F & $\sqrt{ }$ & & \\
\hline 7 & GURU G & $\sqrt{ }$ & & \\
\hline 8 & GURU H & $\sqrt{ }$ & & \\
\hline 9 & GURU I & $\sqrt{ }$ & & \\
\hline 10 & GURU J & $\sqrt{ }$ & & \\
\hline 11 & GURU K & & $\sqrt{ }$ & \\
\hline \multicolumn{2}{|c|}{ JUMLAH } & 10 & 1 & \\
\hline \multicolumn{2}{|c|}{ PERSENTASE } & $90,91 \%$ & $9,09 \%$ & \\
\hline
\end{tabular}


Ngumpriyatun

Berdasarkan data di atas dapat dilihat bahwa guru yang tercapai proses pembelajaran ada 10 orang guru atau $90,91 \%$, sedangkan guru yang tidak

tercapai proses pembelajaran ada 1 orang guru atau $9,09 \%$. Jika dibuat dalam bentuk diagram yaitu:

Diagram 4.9

Disiplin dalam Proses Pembelajaran Guru Siklus II

\begin{tabular}{|c|c|c|c|}
\hline \multirow{3}{*}{\multicolumn{2}{|c|}{ 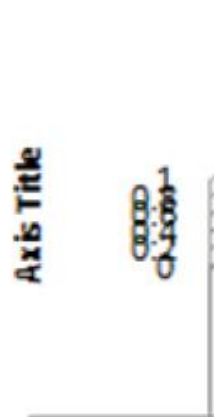 }} & \multicolumn{2}{|c|}{ Siklus II } \\
\hline & & $\sqrt{2}$ & $=$ \\
\hline & & $\begin{array}{c}\text { Tercapai Proses } \\
\text { Pembelajaran }\end{array}$ & $\begin{array}{c}\text { Tidak Tercapai } \\
\text { Proses } \\
\text { Pembelajaran }\end{array}$ \\
\hline & $\mathrm{KA}$ & & \\
\hline & SIKLUS I & & \\
\hline & SIKLUS II & $90.91 \%$ & $9.09 \%$ \\
\hline
\end{tabular}

Berdasarkan dokumen evalusi berupa ketercapaian kegiatan proses pembelajaran yang didapat dari setiap guru diperoleh data sebagai berikut: 10 orang atau sekitar 90,91\% mencapai target kegiatan pembelajaran, dan 1 orang atau 9,09\% tidak mencapai target kegiatan pembelajaran.

Berdasarkan pelaksanaan tindakan pada siklus II menunjukan bahwa disiplin waktu guru sudah mengalami peningkatan yang pada siklus I hanya sekitar $63,64 \%$, pada siklus II ini sudah mencapai $90,91 \%$, demikian halnya dalam disiplin dalam mengadakan persiapan perangkat administrasi pembelajaran yang tadinya siklus I hanya $63,64 \%$ atau 7 guru dari jumlah guru pada siklus II sudah meningkat mencapai $100 \%$ atau 11 guru.

Dari hasil observasi dan data yang diperoleh, peneliti mengambil kesimpulan bahwa tindakan yang dilaksanakan pada siklus II dinyatakan berhasil.

\section{Kesimpulan}

Kedisiplinan guru di SDN Ketawang Karay I Kecamatan Ganding Kabupaten Sumenep Semester 1 Tahun 2017/2018 kondisi awalnya sangat rendah, kemudian kepala sekolah atau peneliti melakukan peningkatan kedisiplinan guru melaui Reward And Punishment. Reward diberikan untuk guru yang berperilaku disiplin dalam mengikuti pembelajaran. Reward yang diberikan berupa pujian (verbal dan nonverbal), penghormatan (pemberian penobatan), hadiah (pemberian alat tulis), tambahan transpot, dan tanda penghargaan (piala). Punishment diberikan untuk guru yang berperilaku tidak disiplin dalam mengikuti pembelajaran. Punishment yang diberikan berupa tugas untuk membina peserta didik yang mempunyai bakat, guru membina peserta didik sesuai keahlian yang dimiliki guru.

Peningkatan kedisiplinan guru melalui Reward And Punishment di SDN Ketawang Karay I Kecamatan Ganding 
Kabupaten Sumenep Semester 1 Tahun 2017/2018 dapat meningkat. Hal ini terbukti dari hasil kondisi awal, kedisiplinan guru dalam kehadiran (guru hadir tepat waktu) ada 3 guru atau $27,27 \%$, meningkat lagi pada siklus I guru yang tepat waktut ada 7 atau $63,64 \%$, dan meningkat lagi pada siklus II menjadi 10 atau 90,91\%. Sedangkan dalam peningkatan disiplin administrasi pada kondisi awal ada 4 orang guru atau $36,36 \%$, mengalami peningkatan pada siklus I ada 7 orang guru atau $63,64 \%$, dan mengalami peningkatan pada siklus II ada 11 orang guru atau $100 \%$. Sedangkan guru yang administrasinya kurang lengkap pada kondisi awal ada 7 orang guru atau $63,64 \%$, mengalami penurunan pada siklus
I ada 4 orang guru atau $36,36 \%$, dan pada siklus II semua guru membuat administrasi dengan lengkap. Peningkatan disiplin dalam proses pembelajaran pada kondisi awal ada 4 orang guru atau 36,36\%, mengalami peningkatan pada siklus I ada 7 orang guru atau $63,64 \%$, dan mengalami peningkatan pada siklus I ada 10 orang guru atau $90,91 \%$. sedangkan guru yang tidak tercapai proses pembelajaran pada kondisi awal ada 7 orang guru atau 63,64\%, mengalami penurunan pada siklus I ada 4 orang guru atau $36,36 \%$, dan mengalami penurunan pada siklus II ada 1 orang guru atau $9,09 \%$. Rata-rata kedisiplinan tersebut sudah sesuai dengan kriteria yang ditentukan oleh peneliti.

\section{DAFTAR PUSTAKA}

Abu Ahmadi dan Nur Uhbiyati. (1991). IImu Pendidikan. Jakarta: Rineka

Amir DaienIndrakusuma. (1993). Pengantar Ilmu Pendidikan. Surabaya: Usaha Nasional.

Cipta. Ali Imron. (2012). Manajemen Peserta Didik Berbasis Sekolah. Jakarta: Bumi Aksara.

Daryanto. Administrasi Pendidikan. Jakarta: Rineka Cipta, 2010.

Erma Masruroh. (2012). Penerapan Metode Reward and Punishment sebagai Upaya Meningkatkan Motivasi Belajar Peserta didik dalam Pembelajaran Akidah Akhlak Kelas VIII C MTs Negeri Ngemplak Sleman.Skripsi, Jurusan Pendidikan Agama Islam Fakultas Tarbiyah Universitas Islam Negeri Sunan Kalijaga Yogyakarta.

Lexy J. Moleong. (2000). Metodologi Penelitian Kualitatif. Bandung: PT. Remaja Rosdakarya.

M.NgalimPurwanto. (2006). IImu Pendidikan Teoritis dan Praktis. Bandung: Remaja Rosdakarya.

Maman Rachman. (1998). Manajemen Kelas. Semarang: Departemen Pendidikan Dan Kebudayaan.

Maria J. Wantah. (2005). Pengembangan Disiplin dan Pembentukan Moral pada Anak Usia Dini. Jakarta: Departemen Pendidikan Nasional.

Peraturan Pemerintah nomer 53 tahun 2010 tentang Disiplin Pegawai Negeri Sipil.

Rita Eka Izzaty, dkk. (2008). Perkembangan Peserta Didik. Yogyakarta: UNY Press.

Suharsimi Arikunto. (2010). Prosedur Penelitian (Suatu Pendekatan Praktik).Jakarta: Rineka Cipta. 